\title{
Culture and Government Money: A Guide for the Perplexed
}

\section{Citation}

Cass R. Sunstein, Culture and Government Money: A Guide for the Perplexed (Public Law \& Legal Theory Working Papers No. 7, 2000).

\section{Published Version}

http://chicagounbound.uchicago.edu/public_law_and_legal_theory/81/

\section{Permanent link}

http://nrs.harvard.edu/urn-3:HUL.InstRepos:12786016

\section{Terms of Use}

This article was downloaded from Harvard University's DASH repository, and is made available under the terms and conditions applicable to Other Posted Material, as set forth at http:// nrs.harvard.edu/urn-3:HUL.InstRepos:dash.current.terms-of-use\#LAA

\section{Share Your Story}

The Harvard community has made this article openly available.

Please share how this access benefits you. Submit a story.

Accessibility 


\section{University of Chicago Law School Chicago Unbound}

2000

\section{Culture and Government Money: A Guide for the Perplexed}

Cass R. Sunstein

Follow this and additional works at: http:// chicagounbound.uchicago.edu/ public_law_and_legal_theory

Part of the Law Commons

\section{Recommended Citation}

Cass R. Sunstein, "Culture and Government Money: A Guide for the Perplexed" (Public Law \& Legal Theory Working Papers No. 7, 2000).

This Working Paper is brought to you for free and open access by the Working Papers at Chicago Unbound. It has been accepted for inclusion in Public Law and Legal Theory Working Papers by an authorized administrator of Chicago Unbound. For more information, please contact unbound@law.uchicago.edu. 


\title{
C H ICAG 0
}

Public Law and Legal Theory W orking Paper N 0.07

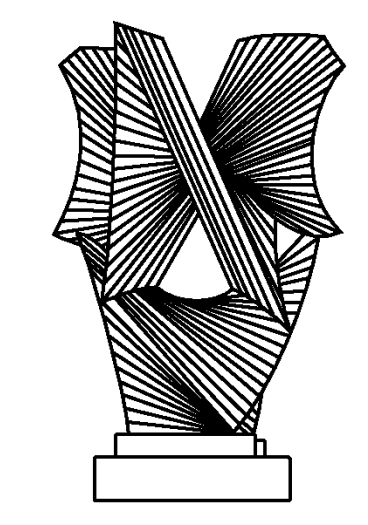

\section{Cult ure and Government M oney: A G uide for the Per pl exed}

\author{
Cass R. Sunstein
}

THE LAW SCHOOL

THE UNIVERSITY OF CHICAGO

This paper can be downloaded without charge at:

The Social Science Research N etwork Electronic Paper Collection: http://papers.ssrn.com/paper.taf?abstract_id=213809 
2/16/00 working paper

All rights reserved

\title{
Culture and Government Money: A Guide for the Perplexed
}

\author{
Cass R. Sunstein*
}

\begin{abstract}
Constitutional limits on government's power to regulate the culture and the arts, newly salient in light of the controversy involving the Brooklyn Museum, are best understood by distinguishing among (a) content-neutral, (b) content-based, and (c) viewpoint-based restrictions, and also among (a) criminal and civil sanctions, (b) "penalties," and (c) mere failure to fund. The resulting three-by-three matrix provides an understanding of the vast bulk of current constitutional law. At the same time, several serious puzzles are created by current law: the distinction between viewpoint discrimination and content discrimination can be thin in the context of art; it is hard to know what counts as a "mere" failure to fund; and the law contains important uncertainties about selective funding. There is discussion as well of government subsidies of the market for culture and art.
\end{abstract}

Government devotes a great deal of money to the promotion of culture. With taxpayer money, the government supports artists, writers, musicians, and private institutions, including museums. But government must be selective; it cannot support all artists, or all museums, all of the time. With respect to culture, what are the limits on government's power? When may government impose criminal or civil restraints, or withdraw benefits, or refuse to fund? These issues have become especially salient in light of Mayor Rudolph Giuliani's effort to withdraw funding from the Brooklyn Museum, an effort growing out of his disapproval of the Museum's controversial decision to display the show "Sensation."

In this essay I attempt to clarify the first amendment issues, principally by exploiting two sets of distinctions. The first is the distinction among 1) criminal and civil remedies, 2) penalties, and 3) "mere" failures to fund. The second is the distinction among 1) viewpoint-based rules, 2) viewpoint-neutral but content-based rules, and 3) content-neutral rules. For present purposes, the first set of distinctions should be

\footnotetext{
" Karl N. Llewellyn Distinguished Service Professor, University of Chicago, Law School and Department of Political Science. This essay was originally produced for a joint School of the Art Institute-University of Chicago conference on issues arising from Mayor Giuliani's effort to withdraw funding from the Brooklyn Museum.
} 
sufficiently clear. The second set of distinctions is designed to separate rules that aim at the speaker's viewpoint ("no one may receive funding whose work opposes Christian theology") from rules that aim at content but not viewpoint ("no one may receive funding unless their work deals with World War II"), and both from rules that do not turn at all on content ("no museum in New York may receive funding unless private donations are under $\$ 100,000$ per year").

To get ahead of the story, and putting some qualifications and complexities to one side, the resulting set of constitutional principles looks like this:

\begin{tabular}{|l|l|l|l|}
\hline & Viewpoint-based & $\begin{array}{l}\text { Viewpoint-neutral, } \\
\text { but content-based }\end{array}$ & Content-neutral \\
\hline Criminal/civil & unconstitutional & Unconstitutional & $\begin{array}{l}\text { Depends on } \\
\text { outcome of a } \\
\text { balancing test }\end{array}$ \\
\hline Penalties & $\begin{array}{l}\text { Unconstitutional } \\
\text { (the Brooklyn } \\
\text { Museum case) }\end{array}$ & $\begin{array}{l}\text { Probably } \\
\text { unconstitutional }\end{array}$ & $\begin{array}{l}\text { Depends on } \\
\text { outcome of a } \\
\text { balancing test }\end{array}$ \\
\hline Mere failure to fund & $\begin{array}{l}\text { Should be and } \\
\text { probably is } \\
\text { unconstitutional }(?)\end{array}$ & $\begin{array}{l}\text { Probably } \\
\text { constitutional } \\
\text { (unless there is } \\
\text { hidden viewpoint } \\
\text { discrimination) }\end{array}$ & $\begin{array}{l}\text { Almost certainly } \\
\text { constitutional }\end{array}$ \\
\hline
\end{tabular}

The essay comes in four parts. Part I deals briefly with the simplest question, involving criminal and civil remedies imposed on art. Part II shifts to the general question of government largesse. After providing a brief treatment of government subsidy of culture, Part II explores the topic of "penalties." Part III investigates the idea of a "mere failure to fund." Part IV is a conclusion, with some observations about first amendment law in this context.

\section{Criminal and Civil Remedies}

The term "censorship" is a loaded and sometimes contested term, but it is usually taken to include any effort to impose criminal sanctions on speech. If the government seeks to criminalize private speech, including art, it faces an extremely heavy burden. Here the question is whether government can fit the speech at issue within the conventional categories of regulable speech, most prominently libel, incitement ("clear and present danger"), commercial speech, and obscenity. These are emphatically narrow categories. ${ }^{1}$ To show incitement, for example, government must demonstrate that the

\footnotetext{
${ }^{1}$ See Stone et al., Constitutional Law (4 ${ }^{\text {th }}$ ed. 1996).
} 
speech at hand is both directed to incite, and likely to incite, imminent lawless action. ${ }^{2}$ It is hard to imagine artistic works that would be regulable under this standard.

Notwithstanding the continuing controversy over whether "obscenity" should be regulable at all, it is clear that museums and artists have little to fear from the Supreme Court's understanding of the constitutional standard. It was obvious, for example, that Robert Mapplethorpe's work could not lawfully be counted as obscene, and his ultimate vindication in court was no surprise to informed observers.

Though the law could have gone otherwise, ${ }^{3}$ what is true for criminal sanctions is equally true for civil remedies. If government authorizes a public enforcement official to collect civil fines for objectionable speech, or if it grants a right of recovery in tort to private litigants, it must meet the ordinary constitutional standards. It will be exceptionally difficult to meet this burden.

There is one qualification to the discussion thus far: Content-neutral restrictions on speech meet a lower standard, one that involves a degree of balancing. ${ }^{4}$ The balancing requires an inquiry into the extent of the intrusion on the speech and the legitimacy and strength of the government's justification for the intrusion. If, for example, government says that people may not use loudspeakers on the public streets after midnight, or may not engage in protected expression on private property, there is unlikely to be a legitimate constitutional complaint. The intrusion in speech is minimal and the government has good reason to protect people from loud noises on the streets after midnight.

For the most part, however, this qualification is irrelevant to government control of art and museums: What would a content-neutral restriction look like in this context? We could imagine, perhaps, a performance artist who sought to defy generally applicable prohibitions on nudity in public places, and here there would be a genuine constitutional issue, with reasonable arguments both ways. But in general, criminal and civil remedies, in this setting, are likely to be based on the content of speech, and as such those remedies are overwhelmingly likely to be unconstitutional.

\section{Penalties}

The discussion thus far involved the simplest and most conventional first amendment cases. Shift now shift to a somewhat more complicated issue, arising whenever government attempts to eliminate "benefits" for those who have engaged in expressive activity of which government disapproves. These are cases involving what the complaining party would like to treat as "penalties" on constitutionally protected activity. The topic, then, is government withdrawal of subsidies. ${ }^{5}$

\footnotetext{
${ }^{2}$ Se Brandenburg v. Ohio, 395 US 444 (1969).

${ }^{3}$ See Schauer, Colum L Rev

${ }^{4}$ See Stone et al., supra.

${ }^{5}$ Of course criminal and civil sanctions can be seen as structurally identical. In such cases, government is also eliminating an entitlement, such as a property right, that is (speaking purely descriptively) governmentally conferred).
} 
To understand this problem, it is necessary to have some understanding of why, exactly, government subsidizes art and culture. As a matter of political reality, the answer lies partly in the self-interest of politicians and the electoral power wielded by people who want government to do exactly this. But there are arguments, and not merely power, involved here. First, art, music, and other cultural products often have a range of external benefits, and those benefits may not be adequately captured by artists and musicians; a government supplement may help to ensure an optimal level of protection. Second, the private market for culture may come with its own strings attached, and it is possible that private funding would ensure underproduction of art that is in some sense novel, unusual, or subversive. (Of course there is no assurance that public funding will sponsor such art.) Third, cultural products are desirable precisely because they are widely shared goods, and help to constitute a culture, providing a kind of social glue. A public museum, or a publicly sponsored celebration of one or another sort, may have exactly this function, which cannot easily be provided through the private sector. Consider, as possible examples, the Vietnam War Memorial in Washington, DC, and the famous "cows" exhibits throughout Chicago in the fall of 1999.

With this background, let us define "penalties' as the denial of benefits that would have been conferred if not for speech to which government objects. In the ordinary refrain, these are "penalties" on the exercise of what is claimed to be a constitutional right. Consider some easy cases from other contexts. A welfare recipient speaks out against the Mayor; welfare benefits are promptly withdrawn. A low-level government employee attends meetings for the Conservative Coalition; she is fired as a result. Someone with a government grant for scientific research turns out to be a member of the Socialist Party; when public officials learn about this fact, they withdraw the grant. In all of these cases, the first amendment has been violated. The government has used its power of "largesse" to punish the exercise of constitutional rights, by denying people benefits to which they would otherwise have been entitled, and by basing the denial on the exercise of constitutional rights.

What does this mean in the cultural context? It means that government cannot withdraw, from a museum or artist, benefits to which either would be entitled, if the reason for the withdrawal is expression that is not independently punishable under the First Amendment. Suppose, for example, that government is leasing public property to a museum, but that in response to an exhibit to which government has objections, government cancels the release, or refuses to renew it (when it otherwise would). This is clearly a penalty, and therefore constitutionally unacceptable. This point is largely sufficient to resolve the problems raised by Mayor Giuliani's effort to withdraw funds from the Brooklyn Museum as a result of a controversial and perhaps offensive exhibit. The best argument on behalf of the Mayor would be that he attempted a "mere" failure to fund (see below). But the facts reveal a penalty (on what would otherwise be the city's course of action), not a mere failure to fund. The reason is that Mayor Giuliani proposed, not merely to deny funding to the exhibit in question, but to withdraw funds that had antecedently been committed to the Museum. There is an important general lesson here about government's power to condition continued benefits on adherence to the government's preferred views about speech content. 
A content-neutral penalty would be in a different category. Suppose, for example, that government finds it necessary to use buildings formerly leased to museums for other purposes, such as military functions or prisons. If so, there is unlikely to be a serious first amendment question. The best challenge would suggest that there is no good reason for the decision not to use the relevant buildings as an outlet for expression - that the shift from expressive to other purposes fails any sensible "balancing test." This would be an uphill battle for plaintiffs, but the basic analysis is straightforward: It involves an assessment of the the strength and legitimacy of the government's purposes, as compared with the burden on expressive activity. This is an analysis that is likely to lead courts to validate content-neutral measures that might otherwise count as objectionable penalties.

\section{Failure to Fund}

When government is simply refusing to fund, its power is at the apex. In funding artistic work, government is inevitably selective, and if it is going to be selective, it is certainly permitted to make distinctions on the basis of content. Indeed, that is what selectivity means in this context. Content discrimination is inevitable. But there are many wrinkles here. They are best explored through distinguishing among a series of cases, actual and imaginable.

1. Discrimination among artists, without discrimination on grounds of content. Suppose that the government is funding private museums, on a per-exhibit basis. Suppose that it decides that for a certain year, it will provide funding only to projects that are done by American artists. It does this on the ground that it wants to support "domestic art." There should be no constitutional problem with this decision. The government has a legitimate interest in funding American artists, and discrimination of this sort does not favor or disfavor any point of view, or indeed favor or disfavor any subject matter or speech of any particular content. To be sure, there might be some indirect connection between American citizenship and artistic content, and the first amendment problem would be heightened if the discrimination were conspicuously responsive to speech of a disfavored content. ${ }^{6}$ But in the absence of clear evidence of an implicit effort to regulate viewpoints, discrimination among artists is entirely acceptable.

This view seems to follow from Regan $\mathrm{v}$. Taxation with Representation of Washington, ${ }^{7}$ where the Court upheld a statute that allowed veteran's organizations, but no other organizations, to deduct political contributions even if a substantial part of their activities were devoted to attempts to influence legislation. The Court emphasized that this distinction was not an effort to aim at the suppression of ideas, and that government could reasonably reward veterans in this way. The decision suggests that discrimination among artists should be generally be acceptable, so long as the discrimination is not a "cover" for viewpoint discrimination. Note that from this conclusion it does not follow that government could reserve funding to those who believe in God or who are prepared

\footnotetext{
${ }^{6}$ Suppose, for example, that government imposed an "Americans only" policy immediately after a general funding program ended up subsidizing art that contained implicit criticisms of American culture.

${ }^{7} 461$ US 540 (1983).
} 
to vote for the Republican party. Efforts of this kind should be invalidated on the ground that they amount to a form of implicit viewpoint discrimination, against both art (indirectly) and artists (directly).

2. Subject matter discrimination. Suppose that the government decides to fund projects, for the year, relating to the subject of American history. Suppose that any museum is permitted to apply for funds, but no proposal will be considered unless it relates to American history. This decision is constitutionally objectionable. The government is not discriminating against any point of view. To be sure, it is favoring material of a certain subject matter, and this step is more controversial than 2 above. But a funding decision limited to a certain topic is unimpeachable.

This answer would be easiest to reach if the funding decision at issue was one of a number of diverse decisions, as, for example, in a case in which one funding agency is selective in one way (American history only), another is selective in another way (World War II only), and yet another is selective in still another way (avant garde art). It would be somewhat harder if the funding restriction were global - if, for example, no government agency could fund art that did not relate to American history. In that case, it would be possible to fear viewpoint discrimination, and here a sense of context should be quite helpful.

3. "Pure" viewpoint discrimination. Suppose now that government engages in unambiguous viewpoint discrimination. Suppose, for example, that it decides to fund projects, for the year, relating to the subject of American history -- but it refuses to consider any project that "casts America or its leaders in an unfavorable light." This is a harder case. At first glance, the refusal might seem plainly unconstitutional.

Discrimination on the basis of viewpoint is he core concern of the first amendment, ${ }^{8}$ and the policy at issue plainly embodies viewpoint discrimination. On the other hand, government itself is perfectly entitled to speak in a viewpoint discriminatory way. If government officials decide, during a period of national celebration, only to celebrate and never to criticize, there would be no offense to the Constitution. Might not government funding be seen as analogous to government speech? If so, might not government be permitted to give funds only to programs of whose viewpoint it approves?

The Court's puzzling and ambiguous decision in Rust v. Sullivan ${ }^{9}$ seems to $^{-}$ support this conclusion. There the Court appeared to held that Congress could discriminate on the basis of viewpoint in the grant of funds to private organizations engaged in family planning. More specifically, the Court said that Congress could require that taxpayer funds will be devoted only to "projects" in which those engaged in family planning do not counsel people about abortion, and do not engage in lobbying, dissemination of materials, and provision of speakers to increase the availability of abortion. In upholding this funding limitation, the Court said that government "has merely chosen to fund one activity to the exclusion of the other," and that its regulations were intended "to ensure that the limits of the program are observed." It added that when

${ }^{8}$ See RAV v. St. Paul.

${ }^{9} 500$ US 173 (1991). 
"Congress established a National Endowment for Democracy to encourage other countries to adopt democratic principles, it was not constitutionally required to fund a program to encourage competing lines of political philosophy such as Communism and Fascism." For the Court, it was crucial that the case involved no penalty but a mere failure to find. Here government "is not denying a benefit to anyone, but is simply insisting that public funds be spent for the purposes for which they were authorized."

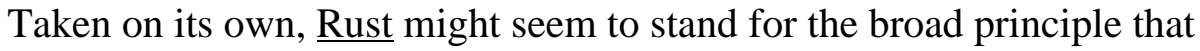
government can allocate its funds however it wishes, and hence that government can give money to the causes that it favors, to promote governmentally preferred points of view. In subsequent cases, however, the Court has raised serious questions about this reading of Rust. In Rosenberger v. Rector and Visitors of University of Virginia,${ }^{10}$ the Court struck down a University of Virginia policy authorizing university subsidies of some student publications, but forbidding subsidies for student publications that "primarily promote or manifests a particular belief in or about a deity or an ultimate reality." The University cited Rust, which appears strongly supportive of the selective subsidy. But the Court distinguished and narrowed its prior decision, in such a way as to leave unsettled the status of viewpoint discrimination in government funding.

The Court explained that government can "regulate the content of what is or is not expressed [1] when it is the speaker or [2] when it enlists private entities to convey its own message." Thus Rust was merely a case in which the government "used private speakers to transmit specific information pertaining to its own program." This means that a government appropriation of "public funds to promote a particular policy of its own" can legitimately be accompanied by appropriate "steps to ensure that its message is neither garbled nor distorted by the grantee." But it does not follow that government may impose "viewpoint-based restrictions" when the government "does not itself speak or subsidize transmittal of a message it favors but instead expends funds to encourage a diversity of views from private speakers." In this case, the University of Virginia did not contend that those who were eligible for university support are the university's agents; student organizations "are not subject to its control and are not its responsibility." Thus when the university has decided to pay private speakers "who convey their own messages," it "may not silence the expression of selected viewpoints."

There is obvious tension between Rush and Rosenberger; and the implications of the two cases, taken together, are far from clear. The distinction seems to be that in Rosenberger, the university did not contend that it was attempting to "convey its own message" or implement "its own program." But what if the university said that its funding policies involved "its own program," broadly speaking? What if the university denied that its purpose was "to encourage a diversity of views from private speakers"? What if the university said that it sought to encourage diversity, but subject to certain restrictions, on the ground that some funding decisions would create too much entanglement between the state and religion? In any case Rosenberger could be understood broadly or very narrowly, and as the opinion is written, it is not clear that it

\footnotetext{
${ }^{10} 515$ US 819 (1995),
} 
stands as a barrier to a government decision to refuse to fund art that it deems offensive, even on the basis of viewpoint.

Compare in this regard the Court's most sustained encounter with question of government funding of the arts, National Endowment for the Arts v. Finley. ${ }^{11}$ There the Court was asked to assess a statute asking the NEA, in establishing procedures to assess the artistic merit of applicants, to "take[e] into consideration general standards of decency and respect for the diverse beliefs and values of the American public." The Court upheld the statute against facial attack; but what is especially important here is what the Court did not say. The Court did not conclude that government could give out taxpayers funds however it chose. It did not accept a "strong" reading of Rust v. Sullivan, which would allow government to choose, in its discretion, its preferred candidates for public subsidization. Instead the Court found it necessary to emphasize that the statute at issue was not, in fact, a form of viewpoint discrimination.

Thus the Court said that the considerations listed in the statute are "susceptible to multiple interpretation," and nothing in law was introduced that "in practice, would effectively preclude or punish the expression of particular views." Both the "decency" and the "respect" criteria could be understood in a constitutional fashion, as, for example, by attempting to give special consideration to "projects and productions . . . that reach, or reflect the culture of, a minority, inner city, rural, or tribal community." Because artistic funding was necessarily based on content discrimination, this case was not covered by Rosenberger, which there was (what the Court called) an indiscriminate effort to encourage a diversity of views from the private sphere. And the Court left open the possibility that in particular cases, "the denial of a grant may be shown to be the product of invidious viewpoint discrimination." Thus any "penalty on disfavored viewpoints" would present "a different case." Justice Souter dissented on the ground that this was in fact a form of viewpoint discrimination; Justice Scalia, joined by Justice Thomas, concurred in the result, invoking a strong reading of Rust and suggesting that government may "earmark NEA funds for protects it deems to be in the public interest without thereby abridging speech."

It is not easy to reconstruct the law as constituted by Rust, Rosenberger, and Finley. The strong version of Rust appears to have been rejected by the Court; unambiguous viewpoint discrimination appears to be impermissible, even with respect to the allocation of government funds for art. On the other hand, government may itself speak as it wishes, and if government wants to create a "program" for a proposed point of view, and to enlist private speakers in the endeavor, it is permitted to do exactly that. Thus, for example, government might have a project for democracy, or a project for the reduction of smoking among teenagers, and it might pay private speakers to help. It might even be possible for government to have a special artistic project whose purpose is to encourage (for example) celebration of the nation's natural beauty. In such cases, Rust would probably govern. But where the government is engaged in a general funding process for art, it is unlikely to be permitted to discriminate on the basis of viewpoint. Of

${ }^{11}$ US 
course the distinction between a specific program and a general funding process is very far from transparent.

4. Genre distinctions and temporal distinctions. Suppose that the government is deciding which museums to fund; suppose too that it chooses to fund museums that offer traditional art, rather than museums that specialize in avant-garde art. This is a somewhat harder case than those discussed those far. The reason is that the line that is being drawn is not merely based on subject matter (which would be acceptable), nor is it based purely on viewpoint (which would be unacceptable). Many artistically informed observers would think that a government distinction of this kind - traditional art yes, avant garde art no -- encodes something more like viewpoint discrimination. Probably the best conclusion is that since government is permitted to fund artistic work of a certain content, it can favor work that fits within aesthetically preferred categories, so long as it is not expressly discriminating against any point of view. If government is refusing to fund art that is perceived to threaten existing government institutions, the argument for invalidation is strengthened. And here too it matters whether the line is local or global.

5. Deference to taxpayers and their sensibilities. In many cases, including Finley and Brooklyn Museum, government is likely to be refusing to fund projects out of deference to the sensibilities - moral, aesthetic, and otherwise - of taxpayers. What is the status of this deference?

Here the key question involves the content of the relevant taxpayer sensibilities. If taxpayers are calling for viewpoint discrimination, the case is no different from case (3) above. If the government's decision is based on the judgment that taxpayers would find the relevant work "offensive to traditional morality," the issue is a bit harder, because the viewpoint discrimination is less obvious. But it seems reasonable to say that in such a case, the government, acting at the behest of taxpayers, is attempting to entrench traditional morality, and this is a form of viewpoint discrimination. This conclusion shows why Finley was such a difficult case; the Court's conclusion that the statutory criteria showed content but not viewpoint discrimination seemed to be rooted in a judgment that they were merely "factors" and did not require government to accept or reject any particular position.

If the government is deferring to purely aesthetic judgments, it is likely to be on firm ground. Here the analysis would be similar to that in 1,2, and 4 above. If the government chooses not to fund a show consisting of avant-garde art, the ground that taxpayers would find the show "confusing" and "ugly," it is probably acting constitutionally, unless there is reason to suspect that something else is at work.

The upshot of this discussion is that deference to taxpayers should be analyzed similarly to any other form of selective funding. What matters is the ground for the selectivity.

6. Withdrawal of funds: A special case? Thus far all of the cases have involved a refusal to fund in the first instance, rather than a withdrawal of funds that have been 
promised. This case appears to fall between a mere failure to fund and an unambiguous penalty. Suppose, for example, that government withdraws support from an exhibit that turns out to have objectionable content; suppose too that no viewpoint discrimination is involved. If this would be acceptable as a failure to fund in the first instance, would it be objectionable if it is a withdrawal of funds already promised?

A more concrete illustration: The government has decided to fund a series of museums. It withdraws funding from several shows of avant garde art. If the government withdraws funding from the museum in general, there is an unambiguous penalty, and the action is unconstitutional. If the government had refused to fund in the first instance, there would be (by hypothesis) no constitutional problem, But suppose that the withdrawal is a genuine withdrawal, not an initial failure to fund, and suppose too that it does not involve general defunding of the museum, but is limited to the shows that were receiving the relevant funding. Is the withdrawal of funds worse than a refusal to fund in the first instance?

It might seem plausible to think that it is. A withdrawal of funds might well offer better evidence of an illicit government motive. When a selective funding agency refuses to give out resources in the first instance, its decision may be based on any number of grounds. And when funds are withdrawn, the case might seem closer to a penalty rather than a refusal to fund. In the case of withdrawn funds, it might seem sensible to say: Here the government is deciding to eliminate a benefit that it would otherwise confer, merely because of the exercise of a constitutional right. But this seems to be little more than a form of wordplay. Unless there really is grounds to believe an illicit motive is at work, and unless there is a penalty in the sense described in Part II above, a withdrawal should probably be treated the same as a failure to fund.

\section{Three Puzzles and A Conclusion}

My purpose in this Essay has been largely descriptive. I have attempted a sympathetic reconstruction of existing law, designed to show some coherence and order, and to generate answers to most of the disputed questions. Notwithstanding the evident order of most of the law, some serious difficulties remain. Consider just three points:

- It is not clear that the distinction between viewpoint discrimination and content discrimination is always coherent, especially in the area of arts funding. At the very least, many forms of content discrimination might be seen (so to speak) as forms of viewpoint discrimination. Suppose, for example, that government has decided that it will not fund avant garde art, or that it wants to restrict the art that it subsidizes to material dealing with American culture. Would we not suspect that these lines embed a form of implicit viewpoint discrimination? Even without such suspicion, might we not think that any such distinction explicitly depends, in one way or another, on a certain viewpoint, embodying judgments about other viewpoints? 
- The line between a penalty and a refusal to fund is far from secure. Whether there is a penalty depends on specification of the normal state of affairs, and when government is frequently involved in funding the arts, identification of the normal state of affairs may be quite unclear. Suppose, for example, that government refuses to fund an exhibit, because that exhibit contains art of which the government disapproves. Why oughn't we to say that the museum is not receiving resources to which it would "otherwise" be entitled, that is, to which it would be entitled if not for its presentation of governmentally disfavored art? The question suggests that many "mere" failures to fund could as well be seen as "penalties." Probably the best solution is to acknowledge the point but to insist that some forms of content discrimination are inevitable so long as government is funding at all. But this solution does not dissipate the difficulty of making the distinction, in principle, between penalizing and failing to fund.

- The Court's decisions in Rust, Rosenberger, and Finley do not suggest anything like a straightforward line between permitted and prohibited arts funding. The special problem is in figuring out whether there is a special program (where selective funding is fine, even if based on viewpoint) or a general set of grants (where viewpoint discrimination is banned). Apparently government is not permitted to make this decision on its own, but it is not clear why, and it is not clear when the government's characterization will be found unacceptable.

These are difficult questions; but it is nonetheless possible to identify principles to resolve the bulk of imaginable problems. Government cannot impose criminal or civil sanctions on speech, outside of a few narrow categories of cases. The analysis of "penalties" proceeds in the same way. If people would otherwise have been entitled to government benefits, the benefits cannot be denied on the ground that people have engaged in speech that is not independently regulable under the first amendment.

The hardest cases involve selective funding decisions, where government is engaging in what it attempts to categorize as a "mere" failure to fund. If government is refusing to fund material for content-neutral reasons, there is most unlikely to be a constitutional objection. If government is refusing to fund material because of a preference for a certain subject matter, there is no constitutional problem, unless the subject matter distinction is suggestive of viewpoint discrimination. Arts funding that involves viewpoint discrimination is forbidden, even if there is a "mere" failure to provide resources - at least outside of contexts in which government explicitly and selfconsciously adopts a specific program to encourage a specific point of view. These conclusions leave many open questions, but they create a framework with which to resolve most real-world disputes, and also to begin inquiries, both practical and theoretical, about the most troublesome cases. 
Readers with comments should address them to:

Cass R. Sunstein

Karl N. Llewellyn Distinguished Service Professor of Jurisprudence The University of Chicago Law School

1111 E. 60th Street

Chicago, IL 60637 